\title{
CITRAAN METAFOR PADA PUISI TEMA COVID-19 KARYA ANAK SEKOLAH DASAR
}

\author{
Metaphorical Imagery in Covid-19 Poetry by Elementary School Children
}

\author{
Herwan $^{1}$ dan Ade Anggraini Kartika Devi ${ }^{2, *}$ \\ ${ }^{1,2}$ Jurusan Pendidikan Bahasa Indonesia \\ Universitas Sultan Ageng Tirtayasa \\ ${ }^{1}$ Pos-el: herwan@untirta.ac.id \\ 2,* Pos-el korespondensi: adekartikadevi@untirta.ac.id
}

\begin{abstract}
In making a poem, elementary school children write metaphors in the scale of their understanding. In other words, the metaphors they wrote were natural, not exaggerated, and not too exaggerated. This study aims to analyze and describe the metaphorical imagery in Covid-19 poetry by elementary school children. The research method used is descriptive qualitative. The data source used was in the form of five poems written by elementary school students in grade 6 F which were obtained from the website of the Darussalam Batam Foundation. The results shows that the metaphor widely used in a Covid-19 poetry is anthropomorphic metaphor because children tend to compare things with similarities in their personal experiences.
\end{abstract}

Keywords: imagery, metaphor, poem, Covid-19

\begin{abstract}
Abstrak: Dalam membuat sebuah puisi, anak SD menulis metafor dalam skala pemahamannya. Dengan kata lain, metafor yang ia tuliskan terasa natural, tidak dibuat-buat, dan tidak terlalu berlebihan. Penelitian ini bertujuan untuk menganalisis dan memerikan citraan metafor pada puisi tema Covid-19 karya anak sekolah dasar. Adapun metode penelitian yang digunakan ialah deskriptif kualitatif. Sumber data yang digunakan berupa lima puisi karya siswa sekolah dasar kelas 6F yang diperoleh dari laman Yayasan Darussalam Batam. Hasil penelitian menunjukkan bahwa metafor yang banyak digunakan dalam puisi bertema Covid-19 ialah metafor antropomorfik sebab anak-anak cenderung membandingkan sesuatu dengan kemiripan pengalaman pribadinya.
\end{abstract}

Kata kunci: citraan, metafor, puisi, Covid-19

\section{A. PENDAHULUAN}

Puisi, bagi anak sekolah dasar, barangkali merupakan sesuatu yang terasa baru. Bagaimana tidak, dalam kehidupan sehari-hari mereka terbiasa berbicara dengan menggunakan bahasa sederhana atau bahasa denotatif biasa, sementara dalam puisi, tentu diperlukan satu aturan baru dalam berbahasanya. Oleh karena itu, dalam ruang pembelajaran menulis puisi di sekolah dasar, guru harus pandai-pandai mengajarkan pilihan kata (diksi) dalam puisi serta bahasa perbandingan (metafor) yang menggambarkan citraan-citraan sederhana dalam ruang lingkup anak-anak usia 6-12 tahun.

Satu di antara hal yang penting dalam menulis puisi adalah metafor. Metafor adalah bahasa perbandingan. Secara etimologi, metafora berasal dari bahasa Yunani, yakni dari kata meta yang berarti $d i$ atas dan kata pherein yang berarti memindabkan sehingga metafora diartikan sebagai pemindahan makna atau citra suatu ungkapan ke dalam ungkapan lainnya. Metafora membandingkan suatu hal dengan hal lainnya tanpa menggunakan kata pembanding: seperti, nak, bagai, dan sebagainya (Keraf, 2009, hlm. 139). 
Struktur dasar metafora sangat sederhana, yakni ada dua hal: sesuatu yang sedang dibicarakan (yang dibandingkan) dan sesuatu yang dipakai sebagai bandingan (Ullman, 2007, hlm. 265).

Kemampuan menyusun metafor yang tepat dan logis akan menggambarkan kecerdasan seorang anak dalam bernalar atau berpikir kritis. Anggapan tersebut tidak berlebihan sebab metafora diungkapkan melalui analogi antara domain target (yang tidak diketahui bahkan sulit ditafsirkan) dan sumber domain (yang lebih mudah dan lebih konkret) sehingga kognisi seseorang dituntut untuk berpikir kritis (Lakoff \& Khonson, 2003). Sebagai contoh, anakanak sekolah dasar pada tahun 2020 dihadapkan dengan pandemi Covid-19. Anak-anak sekolah dasar mampu mengungkapkan keresahan, ketakutan, bahkan kebahagiaannya atas kehadiran Corona melalui bait-bait puisi dengan menggunakan metafor-metafor, misal ketika seorang anak menuliskan metafor: Wabai Corona, kau adalah virus nakal. Dalam hal ini, tentunya anak sudah bisa membandingkan antara posisi virus corona dengan seseorang (anak) yang nakal. Hal tersebut menjadi unik sebab seorang anak SD menulis metafor atau bahasa bermajas dalam skala pemahamannya. Dengan kata lain, metafor yang ia tuliskan terasa natural, tidak dibuat-buat, dan tidak terlalu berlebihan.

Berbeda halnya dengan metafor yang ditulis oleh orang dewasa misalnya. Metafor tentang virus Corona tentu tidak akan disebut sebagai "virus nakal", tetapi bisa jadi ditulis sebagai "virus jahat", "virus setan", bahkan "virus gila", dan sebagainya. "Emosi" yang meledak di dalam metafor orang dewasa akan sangat terasa. Akan tetapi, dalam metafor anakanak, metafor tersebut terasa tenang dan damai. Di sinilah, "kenaturalan" metafor pada puisi anak-anak. Metafora anak-anak terasa benar-benar metaforis. Artinya, metafora yang dibuat oleh anak-anak memanglah bermakna, bukan sesuatu yang diciptakan tanpa kesengajaan (Vosniadou, 1986, hlm. 12).

Keberterimaan metafor yang ditulis oleh anak-anak lainnya inilah yang kadang menjadi sebuah persoalan jika guru tidak mengarahkan pada cara-cara menulis puisi yang baik, yang sesuai dengan usia dan kelas anak. Hal ini pula yang kemudian menjadi dasar pemikiran dalam latar belakang kajian penelitian ini. Citraancitraan metafor yang dipantulkan oleh metafor yang ditulis anak merupakan pembahasan yang akan dikaitkan dengan tahap-tahap psikologi perkembangan anak.

Gagasan Beekman \& Callow menyebut bahwa sebuah metafor terdiri atas tiga bagian: topik, citraan, dan kemiripan (Parera, 2004, hlm. 119). Sedangkan menurut Ullman (2007, hlm. 267) dan Parera (2004, hlm. 119) membedakan metafora menjadi 4 kelompok, yaitu metafora bercitra antropomorfik, metafora bercitra hewan, metafora bercitra abstrak ke konkret serta sebaliknya, dan metafora bercitra sinestesia atau pertukaran tanggapan persepsi indera. Pendapat Ullman dan Parera inilah yang kemudian menjadi dasar pijakan teori tulisan. Puisi-puisi yang ditulis oleh anak-anak SD dengan bertema Covid-19 akan dibedah dalam sisi metafornya. Dalam artian, apakah metafor yang ditulis oleh anak-anak bercitra antropomorfik, hewan, abstrak ke konkret, atau sinestesia?

Kajian yang terkait citraan metafora dalam puisi anak bukan kali pertama dilakukan. Sebut saja Syah et al. (2019) yang melakukan kajian Metafora Konseptual Cinta dalam Album Taylor Swift. Hasil penelitiannya menunjukkan bahwa ada beberapa konseptualisasi yang ditemukan dalam metafora bertemakan cinta, antara lain cinta sebagai tangisan, konsep cinta sebagai lagu, konsep cinta sebagai benda tersembunyi, konsep cinta sebagai suatu kebutuhan, konsep cinta sebagai 
keindahan, dan konsep cinta sebagai kesempurnaan. Kajian Iswani et al. (2017) tentang Analisis Citraan Puisi Anak dalam Majalah Bobo menunjukkan hasil bahwa citraan yang terdapat dalam puisi anak yang dipublikasikan dalam majalah Bobo, yaitu citraan penglihatan, pendengaran, perabaan, penciuman, gerak, dan perasaan.

Berdasarkan kajian tersebut, belum ditemukan yang secara spesifik membahas citraan metafora dalam puisi anak bertema Covid-19. Untuk itulah, peneliti melakukan kajian citraan metafor pada puisi tema Covid-19 karya anak sekolah dasar. Kajian ini menarik untuk dilakukan sebab selain beberapa hal yang telah dikemukakan sebelumnya, puisi anak tema Covid-19 sesuai dengan konteks kekinian.

\section{B. METODE}

Penelitian ini menggunakan pendekatan kualitatif. Pendekatan kualitatif digunakan untuk membuat gambaran kompleks, meneliti kata-kata, dan melakukan studi pada situasi yang alami (Creswell, 2016). Sesuai dengan tujuan penelitian ini, yakni menganalisis dan memerikan citraan metafora pada puisi tema Covid-19 yang dibuat oleh anak sekolah dasar, metode yang digunakan ialah deskriptif. Data berupa lima puisi tentang Corona yang dibuat oleh kelas 6F yang diperoleh dari laman Yayasan Darussalam Batam (bttps:// darussalambatam.com). Analisis data dilakukan dengan menggunakan empat klasifikasi metafora menurut Ullman (2007) \& Parera (2004) yang kemudian dikaitkan psikologi perkembangan anak.

\section{PEMBAHASAN}

Kelima puisi bertema Covid-19 yang ditulis oleh anak-anak sekolah dasar akan dibahas melalui empat kelompok metafora: metafora bercitra antropomorfik, metafora bercitra hewan, metafora bercitra abstrak ke konkret, dan metafora bercitra sinestesia atau pertukaran tanggapan persepsi indera.
Setelah metafor sudah dikelompokan dalam jenis metafor di atas, ditarik hubungan kesesuaiannya dengan teori psikologi perkembangan anak usia $6-12$ tahun, baik dari segi perkembangan bahasa, perkembangan sosial, perkembangan kognitif, ataupun perkembangan moral.

\section{Analisis Puisi Corona Karya Aan}

\section{Corona}

Masih dalam renungan sisa-sisa Subuh Kicauan burung pun masih terdengar merdu Melukiskan keindahan langit yang gemuruh Diiringi dengan arakan awan yang di sapu Pagiku terasa kian merana

Sebab selimut yang menutupinya

Kurasa bahagia di sana

Oleh suasana akibat corona

Ya Tuhanku segeralah Engkau ambil tentara kecilmu

Yang selama ini menyelimuti ketakutanku

Dunia sudah di sini membisu

Kapankah ini semua kan berlalu

$\mathrm{Ku}$ ingin kembali berangkat sekolah

Kurindu suasana yang terindah

Bersama kawan dan jumpa guru

Dalam untaian bahasa kalbu dan kilaunya ilmu

Pada puisi berjudul Corona karya Aan, ditemukan jenis metafora antropomorfik pada kalimat: Masih dalam renungan sisa-sisa Subuh. Kata sisa-sisa, mengacu pada pemakaian bahasa yang ingin membandingkan kemiripan pengalaman individu atau seseorang yakni ketika dia merasakan adanya sisa makanan (misalnya), atau sisa minuman (dalam hal ini mengacu pada pengalaman anakanak) - tentu menjadi berbeda citranya ketika digabungkan dengan kata Subuh.

Gabungan kalimat sisa-sisa Subuh, memperlihatkan gejala metafor jenis antropomorfik. Pengertian kalimat: sisasisa Subub seolah penulisnya ingin membandingkan pengalaman dirinya terhadap pemahamannya pada kata sisa, yakni tinggal sedikit atau yang tersisa, atau yang tinggal dalam jumlah sedikit apabila sesuatu itu dalam hitungan volume dan 
jumlah. Maka dari itu, kalimat: sisa-sisa Subuh, seolah ingin menggambarkan waktu Subuh yang benar-benar sudah menjelang pagi atau mendekati matahari terbit dengan benar-benar sempurna. Bila diibaratkan dengan penunjukan waktu, barangkali bisa ditafsir maksud dari penulisnya adalah waktu Subuh yang sudah mendekati pukul 05.45, yakni ketika semburat cahaya matahari sudah mulai tampak kemerahan di ufuk Timur.

Penunjukan gejala adanya metafor antropomorfik juga terlihat pada kalimat puisi berikutnya masih karya Aan, yakni pada kalimat: pagiku terasa merana, sebab selimut yang menutupinya. Kata selimut merupakan bentuk pengalaman individu si anak ketika tidur pada malam yang dingin di kamarnya. Pengalaman menggunakan selimut ini kemudian tercurahkan dalam bentuk perbandingan yang lain selain dari tubuhnya, yakni ia bandingkan pada kata pagiku.

Citraan yang dimunculkan pada gabungan kalimat tersebut menghasilkan citraan antropomorfik, yang menyiratkan kembali satu gejala semesta, yakni pemakai bahasa ingin membandingkan kemiripan pengalaman pribadinya dengan yang terdapat pada dirinya dengan peristiwa semesta; dalam hal ini bila merujuk pada puisi karya Aan maka kata pagi adalah merujuk pada semesta.

Adanya metafora jenis antropomorfik juga terdapat pada larik puisi sebelumnya, yakni pada kalimat: diiringi dengan arakan awan yang disapu. Kembali bisa dilihat bahwa kata sapu, adalah bentuk pengalaman pribadi penulisnya di lingkungan kesehariannya. Manakala kata ini disandingkan dengan kata: arakan awan maka sudah pasti bahwa penulis ingin membandingkan kemiripan pengalaman pada kata sapu, dengan arakan awan yang tampak bergerak, seolah-seolah dalam bayangan dirinya awan tersebut disapu, mungkin bisa dilanjutkan bisa kita terjemahkan bahwa awan bergerak karena disapu oleh angin.
Jenis metafora antropomorfik juga ditemukan pada larik berikutnya masih dalam puisi karya Aan. Kalimat: ya Tubanku, segeralab Engkau ambil tentara kecilmu. Pada larik ini metafora jenis antropomorfik dilekatkan pada manusia dengan citra rasa humor, ironi, dan figuratif atau konotasi. Penulis ingin membandingkan kemiripan virus Corona (yang dalam ilmu kedokteran memang jauh lebih kecil dari "amuba")dibandingkan dengan sepasukan tentara yang dalam imajinasi Aan berjumlah sangat banyak. Kata tentara bisa ditafsir sebuah regu pasukan yang sangat sigap, sedang mengemban sebuah tugas "penyerangan". Maka dari itu, seolah pula, bahwa Aan ingin melukiskan virus Corona tengah menyerang manusia atas sebuah tugas yang sedang diembannya oleh Tuhan sehingga Aan seolah memohon kembali kepada Tuhan untuk segera mengambil kembali bala tentara kecil, yaitu virus Corona tersebut.

Metafor antropomorfik berikutnya ditemukan kembali pada larik : dunia sudab diam membisu. Kata diam, tentu merupakan pengalaman individu seorang Aan ketika ia sedang tidak berbicara. Aan ingin membandingkan kembali dengan keadaan dunia yang kini seolah "diam dan tidak bisa lagi berbicara atau banyak berkata", bahkan Aan menambahkannya dengan kata membisu. Sebuah keadaan yang benarbenar sunyi dan sepi tanpa kata-kata.

\section{Analisis Puisi Corona Karya Anindya}

\section{Corona}

Virus Corona

Hewan kecil yang mematikan

Dan mengambil nyawa orang-orang di dunia

Dan kini dunia tidak aman

Virus corona

Kembalilah ke tempat asalmu Jangan membuat gaduh dunia 
Untuk keselamatan bumiku

Bertahanlah Indonesia

Untuk mengembalikan nyamanmu

Berjuanglah Indonesia

Agar tidak kehilangan rakyatmu

Pada larik kedua puisi Corona karya Anindya di atas sudah menunjukkan adanya gejala metafor bercitra hewan. Lihat larik: hewan kecil yang mematikan, dan mengambil nyawa orang-orang di dunia. Namun, pencitraan hewan kecil yang sederhana tapi mematikan itu kemudian Anindya bandingkan dengan kata: mengambil nyawa orang-orang di dunia. Bila ditinjau dari pencitraan antropomorfik tentu hal ini bukan menjadi pengalaman pribadi penulisnya. Walaupun secara analisis, boleh jadi bahwa kata mengambil nyawa bisa termasuk ke dalam jenis metafora antropomorfik, yakni apabila dipisahkan kata mengambil dan nyawa maka sudah jelas, bahwa kata mengambil, adalah pengalaman pribadi Anindya. Misalkan mengambil minuman, mengambil nasi, mengambil uang, dan sebagainya. Terbayangkan bahwa kata mengambil sudah barang tentu menggunakan tangan, dengan jari-jemari yang lengkap. Akan tetapi ketika kata itu digabungkan dengan kata nyawa, menjadi : mengambil nyawa, maka sudah pasti ini akan menjadi sebuah pengalaman yang sangat abstrak, penuh ironi dan figuratif. Seolah-olah nyawa seseorang begitu dengan mudahnya "diambil" seperti halnya tangan mengambil uang di saku. Namun ini merupakan keunikan bahasa yang terjadi pada anak-anak yang apabila dikaitkan dengan psikologi perkembangan sosial dan kognitifnya, mereka belum memahami bagaimana proses malaikat mencabut nyawa. Mencabut nyawa tidak semudah tangan mengambil sesuatu yang terkesan begitu ringan dan mudah. Akan tetapi, demikianlah kejujuran cara pandang mata anak-anak terhadap proses kematian atau maut sekalipun. Mereka masih memandangnya dengan cara yang sederhana dan apa adanya, sesuai dengan sentuhan pengalaman pribadinya.

Keunikan dan kepolosan cara pandang anak itu juga tampak pada lariklarik berikutnya dalam puisi karya Anindya ini. Pada larik berikut.

Virus corona kembalilah ke tempat asalmu Jangan membuat gaduh dunia Untuk keselamatan bumiku

Virus Corona yang telah membuat dunia gempar dan meradang dalam banyaknya tangisan dan kucuran air mata duka, dalam pandangan Anindya hanya dilukiskan dengan kata: jangan membuat gaduh dunia. Pengalaman anak-anak yang muncul sebagai perbandingan pada kata gaduh telah menghasilkan metafor jenis antropomorfik. Cara pandang anak hanya sebatas pada membuat gaduh, sebagaimana pengalaman dirinya ketika terasa suasana gaduh di rumah.

Bila dikaitkan dengan teori psikologi perkembangan sosial, maka kata gaduh ini memperlihatkan bahwa anak yang menulis puisi ini sudah memahami kata "gaduh" yang berarti melebihi kata "ramai". Kata gaduh, biasanya ditemukan dalam suasana dan ruang lingkup sosial di sekitar pasar atau terminal. Maka dalam hal ini, secara psikologi perkembangan sosialnya, si anak yang menulis puisi ini, memiliki pengalaman sosial sudah sampai pada batas daerah pasar atau terminal. Kita kemudian bisa membayangkan bahwa Anindya adalah anak SD yang berusia sekitar 10-12 tahunan.

\section{Analisis Puisi Terima Kasih Corona Karya Gubahan K. Tsaqif M.}

\section{Terima Kasih Corona}

Terimakasih Corona

Kini kami sadar dunia tidak kan lama

Setiap saat mendekati sirna

Terimakasih Corona

Kini kehangatan rumah kembali terasa

Bersama kehdiran keluarga tercinta 
Dan kami pun mulai terbiasa

Tetp tinggal di rumah

Dan hidup sederhana

Terimakasih Corona

Kini Negara mau tidak mau harus memperhatikan rakyat

Banyak elit dan pejabat yang tersumbat

Padahal sebelumnya selalu bising berdebat

Terimakasih corona

Kini penyembah dunia merasa tertampar Bahwa Syariat Islam, holistik dan universal Siapa yang menghidupkan sunnah akan selamat Sedang yang masih bertahan dengan gaya hidup berlebihan dan mengumbar maksiat pertanda alamat akan segera tamat

Puisi ini terasa sangat unik dan di luar dugaan apabila mengacu pada tingkat psikologi perkembangan penulisnya masih anak sekolah dasar. Dekonstruksi pemikiran terbalik yang terdapat di dalamnya merupakan pemikiran yang di luar dugaan, dan sama sekali berbeda dengan pemikiran anak-anak pada umumnya yang sederhana dan cenderung sama. Namun pada puisi ini tampak sekali perbedaan "kadar" puisi, bahwa di luar dugaan, pemikirannya begitu jauh dan luas, seperti pemikiran orang dewasa umumnya bahkan orang dewasa yang memiliki pengetahuan dan pendidikan yang tinggi.

Jenis metafor yang terdapat dalam puisi ini masih berkutat pada metafor antropomorfik. Pengalaman individu anak sekolah dasar yang mengetahui rasa "terima kasih" ketika ia mengucapkan pada seseorang dibandingkan dengan kehadiran virus Corona yang telah membuatnya menjadi semakin dekat dan hangat dengan keluarga yang terus berkumpul di rumah setiap hari.

Akan tetapi, yang paling mengejutkan, manakala pemikiran yang ia utarakan berbanding terbalik dengan pemikiranpemikiran anak SD pada umumnya. Bahkan perbedaannya seperti langit dan bumi. Secara analisis psikologi perkembangan, apakah yang sudah terjadi dalam diri Gubahan $\mathrm{K}$ Tsaqif sehingga ia begitu paham soal syariat Islam dengan berbagai hal persoalan sunahnya segala? Ini sangat di luar dugaan pembaca tentunya yang menilai penulis adalah masih anak Sekolah Dasar.

Pada bait pertama sampai bait akhir, tetap bahwa Gubahan Tsaqif mempertahankan asumsinya bahwa virus Corona adalah penyebab kehangatan keluarga kembali pulih, membuat berkumpulnya ia dengan keluarga. Apakah yang terjadi sebelumnya dalam rumah tangga Gubahan? Barangkali juga Gubahan Tsaqif ingin memperlihatkan sebuah ironisme dalam pengalaman dirinya dibandingkan dengan kondisi zaman ini?

\section{Analisis Puisi Oh... Corona Karya Fawnia Najla Habibah}

\section{Oh...Corona}

Kau tak terlihat

Tapi kau menyebar ke seluruh negeri

Siapa yang tak kenal kamu

Semua mengenal kamu

Oh...Corona

Kamu virus nakal

Karena kamu, kami tidak bisa sekolah

Kami tidak bisa bermain

Kami tidak bisa bertemu ibu guru

Kami di rumah saja

Tapi kami tidak takut padamu

Kami akan selalu menjaga kebersihan

Rajin cuci tangan pakai sabun

Agar kamu cepat pergi

Allah akan selalu melindungi kami

Puisi karya Fawnia Najla Habibah menggunakan metafor Kamu virus nakal yang merupakan jenis metafor abstrak ke konkret. Sebagai virus, Corona merupakan sesuatu yang abstrak, tetapi oleh penulis digambarkan menggunakan kata nakal, seperti sifat seseorang yang suka berbuat tidak baik. Secara langsung, pemakai bahasa membandingkan virus dengan tingkah laku seseorang yang mengganggu dan menyusahkan banyak orang. Maka dari itu, penggunaan metafor virus nakal dipilih olehnya. Lebih lanjut, metafor virus 
nakal merupakan ekspresi khas anak-anak. Metafor virus nakal terasa sederhana, tetapi ekspresif.

\section{Analisis Puisi "Corona" Karya Zidan}

\section{Corona}

Ukuranmu sangat kecil

Tapi engkau dapat mengguncangkan dunia Jika engkau tentara Allah

Yang bertugas untuk menyadarkan dunia Maka...

Segera kan lah tugasmu

Pada bait di atas, Zidan membandingkan virus Corona yang berukuran sangat kecil dengan tentara Allah. Tentara Allah merupakan metafora antropomorfik karena mengalihkan virus ke manusia, yakni 'tentara'. Zidan membandingkan kemiripan virus Corona dengan sepasukan tentara yang bertugas. Lebih lanjut, Zidan melekatkan 'tentara' dengan 'Allah' dalam rangka menggambarkan virus corona sebagai utusan-Nya untuk memberi peringatan kepada manusia. Zidan mengimajinasikan virus Corona sebagai 'tentara Allah' seperti layaknya pasukan yang sudah sangat terlatih yang siap melaksanakan perintah untuk menangani persoalan genting. Zidan sebagai anak laki-laki cenderung menyukai tokoh-tokoh heroik. Maka dari itu, tidak mengherankan jika Zidan memilih metafor 'tentara Allah'.

\section{PENUTUP}

Metafor yang banyak digunakan dalam puisi bertema Covid-19 ialah metafor antropomorfik. Adapun citraancitraan yang cenderung ditulis oleh anak dalam sebuah puisi, secara umum, adalah citraan yang sesuai dengan psikologi perkembangan anak di kelas dan usianya. Selain itu, metafor-metafor yang ditulis dalam puisi anak yang bertema Covid-19 mampu menumbuhkan rasa kemanusiaan dalam diri anak-anak. Sesuai dengan apa yang pernah dituliskan oleh Tarigan, dalam bukunya yang berjudul Psikosastra, sastra anak (termasuk puisi anak) mampu mengembangkan perilaku insani anakanak serta mampu mengembangkan rasa sosial dan moral.

\section{DAFTAR PUSTAKA}

Creswell, J. W. (2016). Research Design, Qualitative \& Quantitative Approaches. Thousand Oaks: Sage Publication.

Iswani, Yusuf. Y., \& Muhklis. (2017). Analisis Citraan Puisi Anak dalam Majalah Bobo. JIM Pendididikan Bahasa dan Sastra Indonesia, 2(1), 99108.

Keraf, G. (2009). Diksi dan Gaya Bahasa. Jakarta: PT Gramedia Pustaka Utama.

Kumpulan Puisi Corona Kelas 6F T.P 20192020 (bttps://darussalambatam.com). (Diakses pada 12 November 2020, pukul 16.00)

Lakoff, G. \& Johnson, M. (2003). Metaphors We Live By. $2^{\text {nd }}$ Edition. Chicago: University of Chicago Press.

Parera, J. D. (2004). Teori Semantik. Edisi Kedua. Jakarta: Erlangga.

Stella, V. (1986). Children and Metaphors. Cambridge: University of Illinois at Urbana.

Syah, Irwan, dkk. 2019. Metafora Konseptual Ccinta dalam Album Taylor Siwft: Kajian Semantik Kognitif. Metahumaniora: Jurnal Bahasa, Sastra, dan Budaya, 9(2), $224-231$.

Taisin, N. J. (2019). Unsur Metafora dalam Puisi Lisan Tradisional Kadazandusun. Rumpun: Jurnal Persuratan Melayu, 7(1), 153-172. https://rumpunjurnal.com/jurnal/i ndex.php/rumpun/article/view/31

Tsirkunova, S. A. (2013). Conceptual Metaphor as a Means for Teaching Critical Thinking Skills. International Journal of Humanities and Social Science, 3(16), $44-48$. 
Ullman, S. (2007). Pengantar Semantik.

Yogyakarta: Pustaka Pelajar. 